\title{
Direct Hyperbilirubinemia
}

National Cancer Institute

\section{Source}

National Cancer Institute. Direct Hyperbilirubinemia. NCI Thesaurus. Code C113768.

Abnormally high level of conjug ated bilirubin in the blood. 